\title{
Triglycerides Isolated from Streptomyces sp. ZZ035 and Their Nuclear Magnetic Resonance Spectroscopic Characters
}

\author{
Xuejiao Wu, Li Xu, Ganjun Yuan*, Yimin Wang, Xuejie Xu \\ College of Bioscience and Bioengineering, Jiangxi Agricultural University, Nanchang, China \\ Email: *sqlygj@126.com
}

How to cite this paper: $\mathrm{Wu}, \mathrm{X}$.J., $\mathrm{Xu}, \mathrm{L}$., Yuan, G.J., Wang, Y.M. and Xu, X.J. (2017) Triglycerides Isolated from Streptomyces sp. ZZ035 and Their Nuclear Magnetic Resonance Spectroscopic Characters. Spectral Analysis Reviews, 5, 1-10. https://doi.org/10.4236/sar.2017.51001

Received: January 8, 2017

Accepted: January 28, 2017

Published: January 31, 2017

Copyright (c) 2017 by authors and Scientific Research Publishing Inc. This work is licensed under the Creative Commons Attribution International License (CC BY 4.0).

http://creativecommons.org/licenses/by/4.0/

\begin{abstract}
Streptomyces sp. ZZ035 isolated from a folk medicinal soil sample in China showed remarkable antimicrobial activities. During the isolation of secondary metabolites, a white crystal powder (1) was isolated from the broth of this strain. Its nuclear magnetic resonance (NMR) and infrared (IR) spectra indicated that it was a complex composed of triglycerides. Next, six $\mathrm{C}_{15-17}$ longchain fatty acids derived from these triglycerides were respectively identified as n-pentadecanoyl, 12-methyltetradecanoyl, 14-methyl pentadecanoyl, palmitoyl, 15-methyl hexadecanoyl and 14-methyl hexadecanoyl using the gas chromatography-mass spectroscopy (GC-MS) technology. Finally, the ${ }^{13} \mathrm{C}$ and ${ }^{1} \mathrm{H}$ assignments of 1 were achieved through the analyses of NMR data. Based on above, their detailed NMR spectroscopic elucidation and meticulous ${ }^{13} \mathrm{C}$, ${ }^{1} \mathrm{H}$ assignments, especially the split peaks and coupling correlation of protons attached on the glycerol carbons, were performed for distinguishing triglycerides from other glycerides and for the identification of the long-chain fatty acids, and which would be helpful to the qualitative and quantitative analyses of tri-, di- and mono-glycerides.
\end{abstract}

\section{Keywords}

Nuclear Magnetic Resonance, Triglyceride, Glyceride, Fatty Acid, Bacteria

\section{Introduction}

Around the reservoir for domestic water in Chinese rural areas, a folk medicinal soil in a dark and moist environment is used to prevent infection and accelerating cure by being spread around the wound after dog bite. To reveal the anti-infection reasons of this soil, a sample was collected in Xianjing Countryside in Zhuzhou County, China, and sixty-one actinomycete strains ZZ01 to ZZ061 
were selectively isolated from this sample [1]. After chemical analysis were performed for discovering strains producing a series of secondary metabolites, the bioactive evaluation showed that thirteen strains had antimicrobial activities against Staphylococcus aureus, Escherichia coli andlor Candida albicans, and then the classification and identification of targeted seven strains indicated that they belonged to the genus Streptomyces [2]. Among them, Streptomyces sp. ZZ035 with remarkable antimicrobial activities against $S$. aureus, E. coli and $C$. albicans was targeted for discovering antimicrobial metabolites. During the isolation of components from the broth of this strain, a white crystal powder was isolated and identified as triglycerides, and many nuclear magnetic resonance (NMR) data including ${ }^{1} \mathrm{H},{ }^{13} \mathrm{C}$, distortionless enhancement by polarization transfer (Dept), heteronuclear single-quantum correlation (HSQC), ${ }^{1} \mathrm{H}-{ }^{1} \mathrm{H}$ correlation spectroscopy $\left({ }^{1} \mathrm{H}-{ }^{1} \mathrm{H} \mathrm{COSY}\right)$ and heteronuclear multiple-bond correlation (HMBC) were obtained for the structural analyses of these triglycerides.

Main ${ }^{13} \mathrm{C}$, ${ }^{1} \mathrm{H}$ signals of tri-, di- and mono-glycerides were fully assigned in previous works [3]-[8], while seldom of them presented the detailed elucidation of those signals in ${ }^{13} \mathrm{C},{ }^{1} \mathrm{H}$ NMR spectra, especially for those carbons and protons of glyceryl groups, $\gamma$-methylene to carbonyl carbons of acyl groups and fatty acid terminals. Another, the chemical shifts $(4.10-4.35 \mathrm{ppm})$ of protons attached on the C-1' of 1-monoglycerides, C-1' of 1, 2-diglycerides, C-1' and C-3' of triglycerides (Figure 1(a)) was very close to each other [3] [4] [5], the assignments of those protons easily confused when some of them were showed in the same ${ }^{1} \mathrm{H}$ NMR spectrum. Moreover, the protons attached on C-1' and C-3' of triglycerides

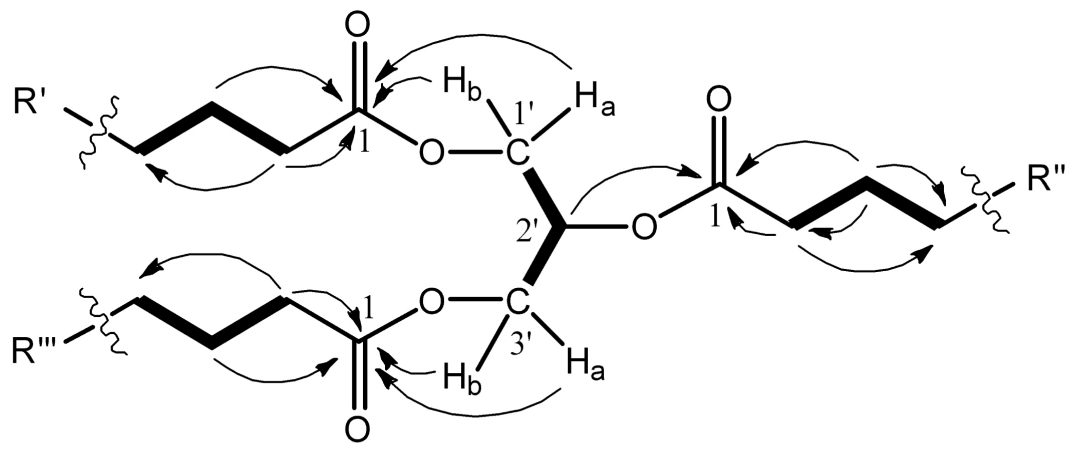

(a)

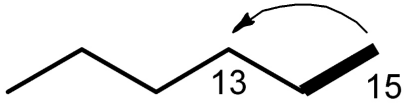

(b)

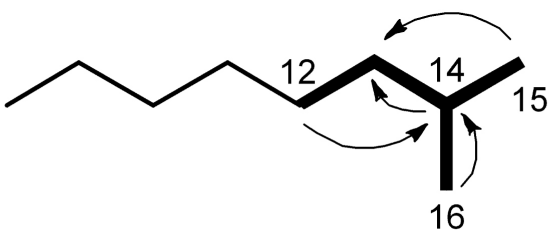

(c)

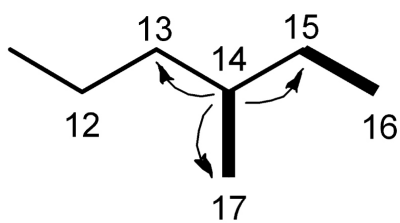

(d)

Figure 1. Key hydrogen-hydrogen correlations and heteronuclear multiple-bond correlations of $\mathbf{1}$. R', the ester acyl linked the carbon-1' of glycerol; R", the ester acyl linked the carbon-2' of glycerol; $\mathbf{R}^{\prime \prime}$, the ester acyl linked the carbon-3' of glycerol; R', R" or R'" was one of six acyl groups identified by gas chromatography-mass spectroscopy technology. 
were indistinctly assigned to a doublet of double doublets centered at $4.22 \mathrm{ppm}$, and the split peaks and meticulous assignments of these protons were not clarified [3] [4] [5] [6] [7]. As many glycerides were widely used in foods, cosmetics and drugs, a variety of analyses in vivo and in vitro usually need to be performed. The detailed NMR spectroscopic elucidation and meticulous ${ }^{13} \mathrm{C},{ }^{1} \mathrm{H}$ assignments of these triglycerides would provide a foundation for NMR technology applying for the qualitative and quantitative analyses of tri-, di- and mono-glycerides. Used triglycerides isolated by us as an example, detailed elucidation of NMR data and meticulous ${ }^{13} \mathrm{C},{ }^{1} \mathrm{H}$ assignments were performed with one dimension (1D) and two dimensions (2D) NMR technology presented in this paper. Some new NMR data for identifying triglycerides were updated, and provided some references for the identification of fatty acids and glycerides.

\section{Materials and Methods}

\subsection{Strain}

Streptomyces sp. ZZ035 was isolated from a soil sample collected in Xianjing Countryside in Zhuzhou County, China (Geographic coordinates: $27^{\circ} 30^{\prime} \mathrm{N}$, $\left.113^{\circ} 17^{\prime} \mathrm{E}\right)[1]$, and was store at $4^{\circ} \mathrm{C}$ in College Bioscience and Bioengineering, Jiangxi Agricultural University, China. Polyphasic taxonomy procedure indicated that this strain belonged to the genus Streptomyces and was closest to $S$. cinnamonensis [2]. Its $16 \mathrm{~S}$ deoxyribonucleic acid ( $16 S \mathrm{rDNA}$ ) sequence was deposited at NCBI GenBank with accession numbers KJ995739.

\subsection{Fermentation and Isolation}

The strain of Streptomyces sp. ZZ035 was cultured in $5000 \mathrm{~mL}$ Erlenmeyer flasks that contained $2000 \mathrm{~mL}$ of $2 \mathrm{~A}$ medium consisting of $1.0 \%$ glucose, $3.5 \%$ soluble starch, $0.2 \%$ yeast, $0.4 \%$ casein, $4.6 \% 3$-[ $\mathrm{N}$-morpholino] propane sulfonic acid, and $1.8 \%$ sodium chloride (W/V) at $28^{\circ} \mathrm{C}$ for $8 \mathrm{~d}$ on a rotary shaker at $190 \mathrm{rpm}$ until $60 \mathrm{~L}$ of broth obtained. The broth was centrifuged to obtain mycelium, and which was extracted with methanol $(\mathrm{MeOH})$. The extract was concentrated under decompression, and then freeze-dried to obtain lyophilized powder. The powder successively dissolved in chloroform $\left(\mathrm{CHCl}_{3}\right)$ to obtained chloroformsoluble fraction, and which was purified using a silica column eluted with chloroform-petroleum ether (10:4). Finally, the fraction contained identical spots on thin layer chromatography (TLC) plates were combined and concentrated to remove solvent, and then the residue was crystallized with $\mathrm{CHCl}_{3}-\mathrm{MeOH}(1: 1)$ at $4^{\circ} \mathrm{C}$ to give a white crystal powder $(1,547 \mathrm{mg})$.

\subsection{Structural Elucidation and Components Analyses}

Thin layer chromatography using for the isolation and analysis was carried out with silica $\mathrm{GF}_{254}$ (Qingdao Haiyang Chemical Co., Ltd, China), and iodine vapor were used as chromogenic agents. All NMR experiments were recorded on a Bruker AV-400 NMR spectrometer equipped with a 5-mm PABBO BB-probe head. The chemical shifts were respectively relative to deuterochloroform 
$\left(\mathrm{CDCl}_{3}\right)$ at $\delta_{\mathrm{H}} 7.26 \mathrm{ppm}$ and $\delta_{\mathrm{C}} 77.0 \mathrm{ppm}$. For the gas chromatography-mass spectroscopy (GC-MS) analyses, the methanolysis of 1 was performed by potassium hydroxide in methanol/hexane, and then the fatty acid methyl esters were determined on a Thermo Trace 1300/ISQ GC-MS spectrometer with an electron ionization (EI) ion source $(70 \mathrm{eV})$. The chromatographic peaks were identified by comparing their mass spectra with those in the NIST 11 MS data library. IR spectrum was determined on a Thermo Nicolet 380 FT-IR spectrometer with potassium bromide pellet.

The template is used to format your paper and style the text. All margins, column widths, line spaces, and text fonts are prescribed; please do not alter them. You may note peculiarities. For example, the head margin in this template measures proportionately more than is customary. This measurement and others are deliberate, using specifications that anticipate your paper as one part of the entire journals, and not as an independent document. Please do not revise any of the current designations.

\section{Results}

\subsection{Structural Elucidation and Components Analyses}

1 was obtained as a white crystal powder, and was easily soluble in chloroform. Assigned to many methylene carbons confirmed by its Dept $135^{\circ}$ and HSQC spectra, a large peak at $29.26-29.95 \mathrm{ppm}$ in its ${ }^{13} \mathrm{C}$ NMR and a corresponding peak at $1.20-1.36 \mathrm{ppm}$ in its ${ }^{1} \mathrm{H}$ NMR indicated that 1 was likely a fatty acid ester [3] [9]. This was also deduced by its IR absorbance peaks at 1745 (Ester, $\mathrm{C}=\mathrm{O}$ ), 1171 (Ester, C-O), 2924 (Methylene), 2854 (Methylene) and $721 \mathrm{~cm}^{-1}$ (More than four methylenes) [10].

The ${ }^{13} \mathrm{C}$ and Dept $135^{\circ}$ NMR spectra of 1 showed two carbonyl carbons at $\delta_{\mathrm{C}}$ 173.23 and 172.86, one methine carbon at $\delta_{\mathrm{C}} 68.89$ and one methylene carbon signal at $62.10 \mathrm{ppm}$. From the HSQC spectra of 1 , two signals at $\delta_{\mathrm{H}} 4.14$ and 4.29 with two double protons observed in its ${ }^{1} \mathrm{H}$ NMR spectrum were attached on the methylene carbon signal at $62.10 \mathrm{ppm}$. This deduced that the signal at $62.10 \mathrm{ppm}$ were assigned to two methylene carbons C-1' and C-3' (Figure 1(a)), and which two double protons at $\delta_{\mathrm{H}} 4.14\left(\mathrm{H}_{\mathrm{a}}-1^{\prime}, \mathrm{H}_{\mathrm{a}}-3^{\prime}\right)$ and $4.29\left(\mathrm{H}_{\mathrm{b}}-1^{\prime}, \mathrm{H}_{\mathrm{b}}-3^{\prime}\right)$ were attached on. Those above together with the IR absorbance peaks at 3446 (br. s), 1745 (s) and $1171 \mathrm{~cm}^{-1}$ deduced that 1 was likely triglycerides, and which was also supported by the ${ }^{1} \mathrm{H}$ NMR data of triglycerides in previous papers [3] [4] [5] [6] [7]. The important ${ }^{1} \mathrm{H}-{ }^{1} \mathrm{H}$ COSY correlations between $\mathrm{H}-1$ ', $\mathrm{H}-3$ ' and $\mathrm{H}-2$ ', and $\mathrm{H}-2$, H-4 and H-3 (Figure 1(a)), together with key HMBC correlations between H-2' and C-1 ( $\left.\mathrm{R}^{\prime \prime}\right), \mathrm{H}_{\mathrm{a}}-1^{\prime} / 3^{\prime}, \mathrm{H}_{\mathrm{b}}-1^{\prime} / 3^{\prime}$ and $\mathrm{C}-1$ ( $\left.\mathrm{R}^{\prime} / \mathrm{R}^{\prime \prime}\right)$, and $\mathrm{H}-2, \mathrm{H}-3$ and $\mathrm{C}-1$ ( $\mathrm{R}^{\prime}, \mathrm{R}^{\prime \prime}$ or $\mathrm{R}^{\prime \prime \prime}$ ) (Figure 1(a)), were further confirmed that 1 was triglycerides.

Four methyl carbons at $\delta_{\mathrm{C}} 22.65,19.21,14.09$ and 11.38 in the ${ }^{13} \mathrm{C}$, Dept $135^{\circ}$ and $90^{\circ}$ spectra deduced three types of fatty acid terminals shown on Figures 1(b)-(d) [9] [11]. As shown on Figure 1(b), a straight chain fatty acid terminal was deduced by the ${ }^{1} \mathrm{H}-{ }^{1} \mathrm{H}$ COSY correlation between proton at $\delta_{\mathrm{H}} 1.27(\mathrm{H}-14)$ and that at $\delta_{\mathrm{H}} 0.88(\mathrm{H}-15)$, and by the $\mathrm{HMBC}$ correlation between $\mathrm{H}-15$ and a 
carbon at $\delta_{\mathrm{C}} 31.92(\mathrm{C}-13)$. Similarly, the correlations between proton at $\delta_{\mathrm{H}} 1.53$ (H-14) and that at $\delta_{\mathrm{H}} 0.86(\mathrm{H}-15$ or H-16), and between proton at $\mathrm{H}-14$, a proton at $\delta_{\mathrm{H}} 1.25(\mathrm{H}-12)$ and $\delta_{\mathrm{H}} 1.15(\mathrm{H}-13)$ in the ${ }^{1} \mathrm{H}-{ }^{1} \mathrm{HCOSY}$ spectrum deduced another fatty acid terminal from $\mathrm{C}-12$ to $\mathrm{C}-16$ shown on Figure $1(\mathrm{c})$. This was further confirmed by the key HMBC correlations between $\mathrm{H}-15$ or H-16 and two carbons respectively at $\delta_{\mathrm{C}} 27.97(\mathrm{C}-14), 39.06(\mathrm{C}-13)$, and between $\mathrm{H}-12$ and C-14 shown on Figure 1(c). According to the ${ }^{13} \mathrm{C}$ NMR data reported [11], two methyl carbons at $\delta_{\mathrm{C}} 19.21$ (C-17) and 11.38 (C-16), two methylene carbons at $\delta_{\mathrm{C}} 27.11(\mathrm{C}-15)$ and $36.65(\mathrm{C}-13)$ and one methine carbon at $\delta_{\mathrm{C}} 34.40(\mathrm{C}-14)$ presented the third fatty acid terminal from C-13 to C-17 shown on Figure 1(d). This was confirmed by the ${ }^{1} \mathrm{H}-{ }^{1} \mathrm{H}$ COSY correlations between $\mathrm{H}-14$ and $\mathrm{H}-17$, and $\mathrm{H}-15$ and $\mathrm{H}-16$, and by the HMBC correlations between $\mathrm{H}-14$ and $\mathrm{C}-17$, C-15 and C-13.

Many carbon signals at $29.26-29.95 \mathrm{ppm}$ and their one-bond related proton signals at $1.20-1.36 \mathrm{ppm}$ in the ${ }^{13} \mathrm{C},{ }^{1} \mathrm{H}$ and HSQC spectra of 1 were assigned to most methylenes of fatty acid chain [3,9]. To understand the carbon numbers composed fatty acid, GC-MS technology was used for the analyses of the fatty acid methyl esters (FAME) synthesized from 1, and six FAME were identified as shown in Table 1 . Thereby, six $\mathrm{C}_{15-17}$ long-chain fatty acyl groups composed of 1 were identified as $n$-pentadecanoyl (1a), 12-methyltetradecanoyl (1b), 14-methyl pentadecanoyl (1c), palmitoyl (1d) and 15-methyl hexadecanoyl (1e) and 14methylhexadecanoyl (1f).

\subsection{Nuclear Magnetic Resonance Data of Triglycerides}

Comparing previous reports [3]-[9] [12], their detailed and meticulous ${ }^{13} \mathrm{C},{ }^{1} \mathrm{H}$ assignments were achieved by the ${ }^{13} \mathrm{C},{ }^{1} \mathrm{H}, \mathrm{HSQC},{ }^{1} \mathrm{H}-{ }^{1} \mathrm{H}$ COSY and HMBC spectra, and shown in Table 2 and Table 3.

\section{Discussion}

These triglycerides were isolated from the broth of Streptomyces sp. ZZ035 derived from a folk medicinal soil sample. Their detailed NMR spectroscopic

Table 1. Fatty acid methyl esters synthesized from 1 detected by gas chromatographymass spectroscopy (GC-MS) technology. ${ }^{\mathrm{a}}$

\begin{tabular}{|c|c|c|c|c|c|}
\hline No. & $\mathrm{RT}(\min )$ & SI & RSI & Compounds & Formula \\
\hline 1 & 26.47 & 848 & 868 & Pentadecanoic acid methyl ester & $\mathrm{C}_{16} \mathrm{H}_{32} \mathrm{O}_{2}$ \\
\hline 2 & 26.61 & 900 & 900 & 12-Methyl tetradecanoic acid methyl ester & $\mathrm{C}_{16} \mathrm{H}_{32} \mathrm{O}_{2}$ \\
\hline 3 & 28.19 & 859 & 879 & $\begin{array}{l}\text { 14-Methyl pentadecanoic acid methyl } \\
\text { ester }\end{array}$ & $\mathrm{C}_{17} \mathrm{H}_{34} \mathrm{O}_{2}$ \\
\hline 4 & 28.80 & 827 & 868 & Palmitic acid methyl ester & $\mathrm{C}_{17} \mathrm{H}_{34} \mathrm{O}_{2}$ \\
\hline 5 & 29.83 & 846 & 896 & 15-Methyl hexadecanoic acid methyl ester & $\mathrm{C}_{18} \mathrm{H}_{36} \mathrm{O}_{2}$ \\
\hline 6 & 29.97 & 829 & 830 & 14-Methyl hexadecanoic acid methyl ester & $\mathrm{C}_{18} \mathrm{H}_{36} \mathrm{O}_{2}$ \\
\hline
\end{tabular}

${ }^{a}$ The GC-MS analyses were determined on a Thermo Trace 1300/ISQ GC-MS spectrometer with an electron ionization ion source $(70 \mathrm{eV})$, and the chromatographic peaks were identified by the NIST $11 \mathrm{MS}$ data library. RT, Retention time; SI, Similarity index; RSI, Reversed search index. 
Table 2. ${ }^{13} \mathrm{C}$ and ${ }^{1} \mathrm{H}$ nuclear magnetic resonance assignments of glyceryl and part long-chain fatty acyl groups $(\delta$, ppm in deuterochloroform). ${ }^{\mathrm{a}}$

\begin{tabular}{|c|c|c|c|c|c|c|c|c|c|}
\hline \multirow[b]{2}{*}{ Position } & \multicolumn{3}{|c|}{$\mathrm{R}^{\prime \mathrm{b}}$} & \multicolumn{3}{|c|}{$\mathrm{R}^{\prime \prime}$} & \multicolumn{3}{|c|}{ R"' } \\
\hline & $\delta_{\mathrm{C}}$ & $\operatorname{Dept}^{\mathrm{c}}$ & $\delta_{\mathrm{H}}(\mathrm{Int}$, mult., $J$ in $\mathrm{Hz})$ & $\delta_{\mathrm{C}}$ & Dept & $\delta_{\mathrm{H}}($ Int, mult., $J$ in $\mathrm{Hz}$ ) & $\delta_{\mathrm{C}}$ & Dept & $\begin{array}{c}\delta_{\mathrm{H}} \text { (Int, mult., } \\
\quad J \text { in } \mathrm{Hz})\end{array}$ \\
\hline 1 & 173.28 & $\mathrm{C}$ & - & 172.86 & $\mathrm{C}$ & - & 173.28 & $\mathrm{C}$ & - \\
\hline 2 & 34.06 & $\mathrm{CH}_{2}$ & $2.31(2 \mathrm{H}, \mathrm{t}, 7.6 \mathrm{~Hz})$ & 34.22 & $\mathrm{CH}_{2}$ & $2.31(2 \mathrm{H}, \mathrm{t}, 7.6 \mathrm{~Hz})$ & 34.06 & $\mathrm{CH}_{2}$ & $2.31(2 \mathrm{H}, \mathrm{t}, 7.6 \mathrm{~Hz})$ \\
\hline 3 & 24.87 & $\mathrm{CH}_{2}$ & 1.61 & 24.91 & $\mathrm{CH}_{2}$ & 1.61 & 24.87 & $\mathrm{CH}_{2}$ & 1.61 \\
\hline 4 & 29.12 & $\mathrm{CH}_{2}$ & 1.34 & 29.08 & $\mathrm{CH}_{2}$ & 1.34 & 29.12 & $\mathrm{CH}_{2}$ & 1.34 \\
\hline $5-n^{d}$ & $29.26-29.9$ & $\left(\mathrm{CH}_{2}\right)_{\mathrm{n}-4}$ & $1.20-1.36$ & $29.26-29$. & $\left(\mathrm{CH}_{2}\right)_{\mathrm{n}-4}$ & $1.20-1.36$ & $29.26-29$. & $\left(\mathrm{CH}_{2}\right)_{\mathrm{n}-4}$ & $1.20-1.36$ \\
\hline $1^{\prime}$ & 62.10 & $\mathrm{CH}_{2}$ & & & & $\begin{array}{l}4.14\left(\mathrm{H}_{\mathrm{a}}, \mathrm{dd}, 6.0,11.9\right) \\
4.29\left(\mathrm{H}_{\mathrm{b}}, \mathrm{dd}, 4.2,11.9\right)\end{array}$ & & & \\
\hline $2^{\prime}$ & 68.89 & $\mathrm{CH}$ & & & & $5.26(\mathrm{H}, \mathrm{tt}, 4.2,6.0)$ & & & \\
\hline $3^{\prime}$ & 62.10 & $\mathrm{CH}_{2}$ & & & & $\begin{array}{l}4.14\left(\mathrm{H}_{\mathrm{a}}, \mathrm{dd}, 6.0,11.9\right) \\
4.29\left(\mathrm{H}_{\mathrm{b}}, \mathrm{dd}, 4.2,11.9\right)\end{array}$ & & & \\
\hline
\end{tabular}

${ }^{\mathrm{a}} 400 \mathrm{MHz}$ for ${ }^{1} \mathrm{H}$ shifts relative to deuterochloroform $\left(\mathrm{CDCl}_{3}\right)$ at $\delta_{\mathrm{C}} 7.26 ; 100 \mathrm{MHz}$ for ${ }^{13} \mathrm{C}$ shifts relative to $\mathrm{CDCl}_{3}$ at $\delta_{\mathrm{C}} 77.0$. ${ }^{\mathrm{R}}$ ', $\mathrm{R}^{\prime \prime}$ or $\mathrm{R}^{\prime \prime}$ was one of six acyl groups 1a-1f identified by gas chromatography-mass spectroscopy technology. 'Dept is the abbreviation of distortionless enhancement by polarization transfer spectrum. ${ }^{\mathrm{d}} \mathrm{n}$ was equal to 9 for acyl $\mathbf{1 b}, 11$ for acyls $1 \mathrm{c}$ and $1 \mathrm{e}, 12$ for acyls $1 \mathrm{a}$ and $1 \mathrm{f}$, and 13 for acyl $1 \mathrm{~d}$.

Table $3 .{ }^{13} \mathrm{C}$ and ${ }^{1} \mathrm{H}$ nuclear magnetic resonance assignments of long-chain fatty acyl terminals $(\delta$, ppm in deuterochloroform). ${ }^{\mathrm{a}}$

\begin{tabular}{|c|c|c|c|c|c|c|c|c|c|}
\hline \multirow{2}{*}{ Position $^{\mathrm{b}}$} & \multicolumn{3}{|c|}{$1 a^{c}$} & \multicolumn{3}{|c|}{$1 c$} & \multicolumn{3}{|r|}{ 1f } \\
\hline & $\delta_{\mathrm{C}}$ & $\operatorname{Dept}^{d}$ & $\delta_{\mathrm{H}}(\mathrm{Int}$, mult., $J$ in $\mathrm{Hz})$ & $\delta_{\mathrm{C}}$ & Dept & $\delta_{\mathrm{H}}($ Int, mult., $J$ in $\mathrm{Hz})$ & $\delta_{\mathrm{C}}$ & Dept & $\delta_{\mathrm{H}}($ Int, mult., $J$ in Hz) \\
\hline 12 & & & & 27.41 & $\mathrm{CH}_{2}$ & 1.25 & 27.22 & $\mathrm{CH}_{2}$ & 1.15 \\
\hline 13 & 31.92 & $\mathrm{CH}_{2}$ & 1.26 & 39.06 & $\mathrm{CH}_{2}$ & 1.15 & 36.65 & $\mathrm{CH}_{2}$ & $1.08,1.26$ \\
\hline 14 & 22.68 & $\mathrm{CH}_{2}$ & 1.27 & 27.97 & $\mathrm{CH}$ & 1.53 & 34.40 & $\mathrm{CH}$ & 1.29 \\
\hline 15 & 14.09 & $\mathrm{CH}_{3}$ & $0.88(3 \mathrm{H}, \mathrm{t}, 6.8)$ & 22.65 & $\mathrm{CH}_{3}$ & $0.86(3 \mathrm{H}, \mathrm{d}, 6.8)$ & 27.11 & $\mathrm{CH}_{2}$ & 1.25 \\
\hline 16 & & & & 22.65 & $\mathrm{CH}_{3}$ & $0.86(3 \mathrm{H}, \mathrm{d}, 6.8)$ & 11.38 & $\mathrm{CH}_{3}$ & $0.85(3 \mathrm{H}, \mathrm{t}, 7.0)$ \\
\hline 17 & & & & & & & 19.21 & $\mathrm{CH}_{3}$ & $0.84(3 \mathrm{H}, \mathrm{d}, 6.7)$ \\
\hline
\end{tabular}

${ }^{a} 400 \mathrm{MHz}$ for ${ }^{1} \mathrm{H}$ shifts relative to deuterochloroform $\left(\mathrm{CDCl}_{3}\right)$ at $\delta_{\mathrm{C}} 7.26 ; 100 \mathrm{MHz}$ for ${ }^{13} \mathrm{C}$ shifts relative to $\mathrm{CDCl}_{3}$ at $\delta_{\mathrm{C}} 77.0$. ${ }^{\text {b }} \mathrm{Positions}$ were numbered according to Figures 1(b)-(d) for acyl terminals Figure 1(a), Figure 1(c) and Figure 1(f). ${ }^{\mathrm{F}}$ Figure 1(a), n-pentadecanoyl terminal (that same to palmitoyl one); Figure 1(c), 14-methyl pentadecanoyl terminal (same to 15-methyl hexadecanoyl one), Figure 1(f), 14-methylhexadec-anoyl terminal (same to 12-methyltetradecanoyl one). Dept is the abbreviation of distortionless enhancement by polarization transfer spectrum.

elucidation and key ${ }^{13} \mathrm{C},{ }^{1} \mathrm{H}$ assignments were performed for distinguishing triglycerides from other glycerides and for the identification of the long-chain fatty acid terminals. More and more glycerides isolated from bacteria and other bioresources, they showed a variety of bioactivities [8] [11] [13] [14] [15]. Some of them showed antimicrobial [8], and some were platelet aggregation inhibitors or antagons of cannabinoid receptor [11] [13] [14]. Our antimicrobial experiments indicated that 1 contained $\mathrm{C}_{15-17}$ fatty acyl groups had no antimicrobial activities against $S$. aureus and C. albicans. Same to most glycerides [8] [9] [11] [12], triglycerides also present a large peak at $29.26-29.95 \mathrm{ppm}$ in their ${ }^{13} \mathrm{C}$ NMR spectra and a large peak at $1.20-1.36 \mathrm{ppm}$ in their ${ }^{1} \mathrm{H}$ spectra NMR spectra. The acyl terminals of glycerides were deduced from the chemical shifts of methyl carbons in their ${ }^{13} \mathrm{C}$ NMR spectra, such as a methyl carbon at $\delta_{\mathrm{C}} 14.09$ for a straight chain acyl terminals, two methyl carbons at $\delta_{\mathrm{C}} 22.65$ for an iso-fatty acid terminal 
(Figure $1(\mathrm{c})$ ), and two methyl carbons at $\delta_{\mathrm{C}} 11.38$ and 19.21 for an anteiso-fatty acid terminal (Figure $1(\mathrm{~d})$ ).

For distinguishing triglycerides from other glycerides, peaks due to protons attached on the glycerol carbons are of primary importance. The chemical shifts of protons on $\mathrm{C}^{-1} \mathbf{1}^{\prime}$ or $\mathrm{C}-3^{\prime}$, and C-2' for triglycerides were respectively 4.22 and $5.27 \mathrm{ppm}$ in $\mathrm{CDCl}_{3}$ according to previous reports [3] [4] [5], while two nonequivalent protons attached on C-1' or C-3' of these triglycerides were deduced from the $1 \mathrm{D}$ and $2 \mathrm{D}$ NMR data of 1 . The chemical shift of one proton was 4.14 $\mathrm{ppm}$, and another was $4.30 \mathrm{ppm}$. Each proton attached on C-1' or C-3' presented a geminal coupling $(J=11.9 \mathrm{~Hz})$ with another and a vicinal coupling $(J=6.0$ or $4.2 \mathrm{~Hz}$ ) with $\mathrm{H}-2$ ', and which gave a double doublets for each proton on $\mathrm{C}-1$ ' or $\mathrm{C}-3^{\prime}$ due to an AMX coupling system. Their ${ }^{13} \mathrm{C}$ and ${ }^{1} \mathrm{H}$ assignments were up to date in Table 2, and the relative split peaks in the ${ }^{1} \mathrm{H}$ NMR spectrum were amplified in Figure 2.

Another, an $\mathrm{A}_{2} \mathrm{MX}_{2}$ coupling system led $\mathrm{H}-2$ ' to split triple-triplets centered at $5.26 \mathrm{ppm}$, among which three middle ones mostly overlapped to form an abnormal peak (Figure 2). These ${ }^{13} \mathrm{C},{ }^{1} \mathrm{H}$ assignments and split analyses of triglycerides were first confirmed by their HMBC and HSQC spectra shown on Figure 1 (a) and Figure 3. Moreover, the chemical shifts of protons attached on the $\mathrm{C}-1^{\prime}$ of 1-monoglycerides $\left(\delta_{\mathrm{H}-1^{\prime}} 4.14 / 4.18\right), \mathrm{C}-1^{\prime}$ of 1,2 -diglycerides $\left(\delta_{\mathrm{H}-1^{\prime}} 4.28\right), \mathrm{C}-1^{\prime}$ and C-3' of triglycerides (Figure 1(a)) was very close to each other [3]-[8], and the assignments of those protons easily confused when some of them were showed in the same ${ }^{1} \mathrm{H}$ NMR spectrum. The clarification of these ${ }^{13} \mathrm{C},{ }^{1} \mathrm{H}$ assignments would be helpful to distinguish triglycerides from other glycerides

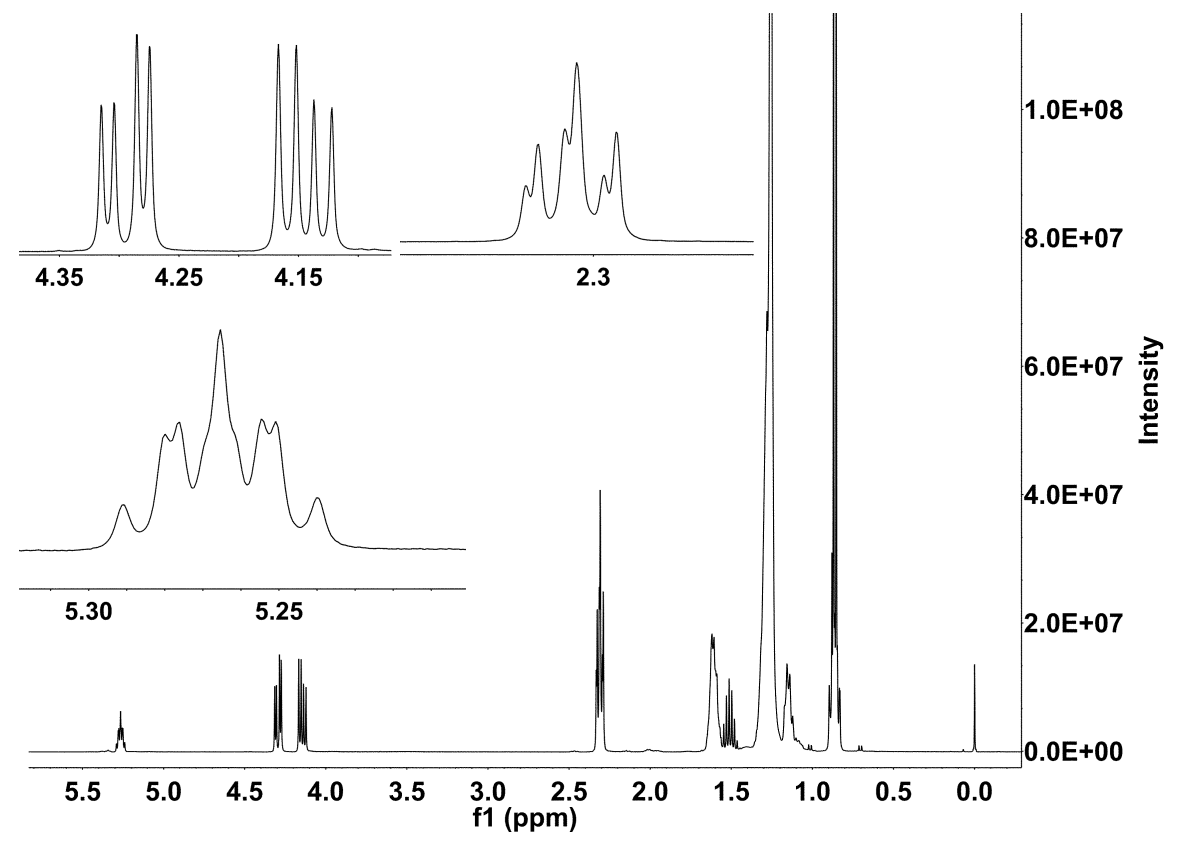

Figure 2. Hydrogen nuclear magnetic resonance spectrum of 1. a, nine split peaks centered at $5.27 \mathrm{ppm}$ were assigned to hydrogen-2 ( $\left.\mathrm{H}-2^{\prime}\right) ; \mathrm{b}$, two double doublets centered 4.14 and 4.30 ppm were respectively assigned to $\mathrm{H}_{\mathrm{a}}-1^{\prime}\left(3^{\prime}\right)$ and $\mathrm{H}_{\mathrm{b}}-\mathrm{1}^{\prime}\left(3^{\prime}\right)$; c, protons attached carbon-2 of R' or R'" (higher field) and carbon- 2 of R" (lower field). 


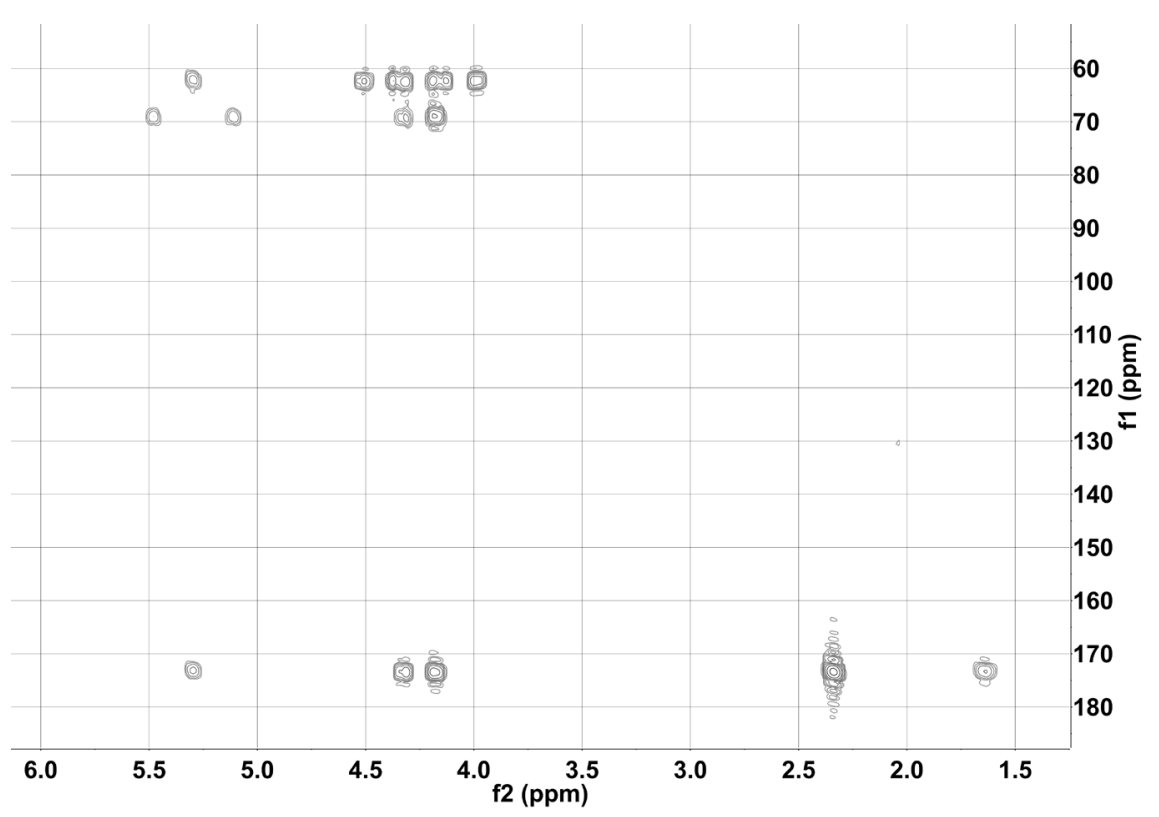

(a)

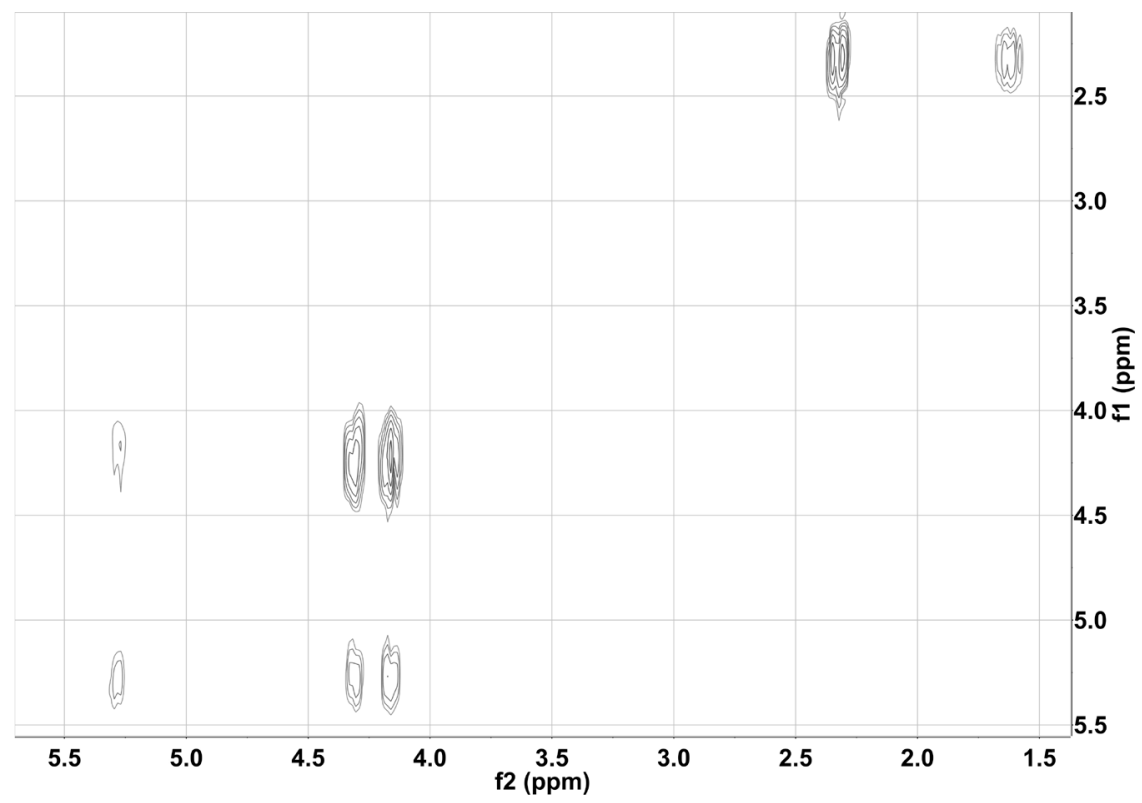

(b)

Figure 3. Part hydrogen-hydrogen $\left({ }^{1} \mathrm{H}^{-1} \mathrm{H}\right)$ correlation spectroscopy (a) and heteronuclear multiple-bond correlation spectrum (b) for the ${ }^{13} \mathrm{C}$ and ${ }^{1} \mathrm{H}$ assignments of glyceryl of 1.

with NMR technology.

As many glycerides were widely used in foods, cosmetics and drugs, a variety of analyses involved determination, metabolism and transformation in vivo or in vitro usually need to be performed [3] [4] [5] [16]. Further, ${ }^{13} \mathrm{C}$ and ${ }^{1} \mathrm{H}$ NMR was proved to be a very useful technique in monitoring the extent of lipid hydrolysis in digestion processes and to determine the bioaccessibility and bioavailability of lipophilic compounds [3] [4] [5] [16] [17]. Thereby, the detailed and meticulous ${ }^{13} \mathrm{C},{ }^{1} \mathrm{H}$ assignments of these triglycerides would provide a foundation for NMR 
technology applying for the qualitative and quantitative analyses of tri-, di- and mono-glycerides.

\section{Conclusion}

A white crystal powder (1) composed of several triglycerides was isolated from the broth of Streptomyces sp. ZZ035, and analysized by GC-MS, IR and NMR technology. The important ${ }^{13} \mathrm{C}$ and ${ }^{1} \mathrm{H}$ assignments of these triglycerides were achieved through the analyses of NMR data. Moreover, their detailed NMR spectroscopic elucidation and meticulous ${ }^{13} \mathrm{C},{ }^{1} \mathrm{H}$ assignments, especially the split peaks and coupling correlation of protons attached on the glycerol carbons, were performed for distinguishing triglycerides from other glycerides and for the identification of the long-chain fatty acids, and which would be helpful to the qualitative and quantitative analyses of tri-, di- and mono-glycerides.

\section{Acknowledgements}

This research was supported by the National Natural Science Foundation of China [No. 81260476 and 81460529] and the University Science Research Project of Jiangxi, China [No. GJJ14277].

\section{References}

[1] Yuan, G., Li, P., Yang, H., Wu, X., Tu, G. and Wei, S. (2012) Chemical Screening of Sixty-One Actinomycete Strains and Anti-Methicillin-Resistant Staphylococcus aureus Assays of Target Strains. Chinese Journal of Natural Medicine, 10, 155-160. https://doi.org/10.3724/SP.J.1009.2012.00155

[2] Xu, X., Wu, X., Yuan, G., Zhong, Q. and Xu, L. (2017) A New Inhibitor of $\gamma$-Aminobutric Acid Aminotransferase from Streptomyces sp. ZZ035 Isolated from a Folk Medicinal Soil in China.

[3] Nieva-Echevarría, B., Goicoechea, E., Manzanos, M.J. and Guillén, M.D. (2016) A Study by ${ }^{1} \mathrm{H}$ NMR on the Influence of Some Factors Affecting Lipid in Vitro Digestion. Food Chemistry, 211, 17-26.

[4] Nieva-Echevarría, B., Goicoechea, E., Manzanos, M.J. and Guillén, M.D. (2015) Usefulness of ${ }^{1} \mathrm{H}$ NMR in Assessing the Extent of Lipid Digestion. Food Chemistry, 179, 182-190.

[5] Nieva-Echevarría, B., Goicoechea, E., Manzanos, M.J. and Guillén, M.D. (2014) A Method Based on ${ }^{1} \mathrm{H}$ NMR Spectral Data Useful to Evaluate the Hydrolysis Level in Complex Lipid Mixtures. Food Research International, 66, 379-387.

[6] Sopelana, P., Arizabaleta, I., Ibargoitia, M.L. and Guillén, M.D. (2013) Characterisation of the Lipidic Components of Margarines by $1 \mathrm{H}$ Nuclear Magnetic Resonance. Food Chemistry, 141, 3357-3364.

[7] Lu, Y., Wang, J., Deng, Z., Wu, H., Deng, Q., Tan, H. and Cao, L. (2013) Isolation and Characterization of Fatty Acid Methyl Ester (FAME)-Producing Streptomyces sp. S161 from Sheep (Ovis aries) Faeces. Letters in Applied Microbiology, 57, 200205. https://doi.org/10.1111/lam.12096

[8] Akeda, Y., Shibata, K., Ping, X., Tanaka, T. and Taniguchi, M. (1995) AKD-2A, B, C and D, New Antibiotics from Streptomyces sp. OCU-42815: Taxonomy, Fermentation, Isolation, Structure Elucidation and Biological Activity. Journal of Antibiotics, 48, 363-368. https://doi.org/10.7164/antibiotics.48.363 
[9] Serdarevich, B. and Carroll, K.K. (1966) Synthesis and Characterization of 1- and 2-Monoglycerides of anteiso Fatty Acids. Journal of Lipid Research, 7, 277-284.

[10] Parkash, S. and Blanshard, J.M.V. (1975) Infrared Spectra of Selected Ultra-Pure Triglycerides. Spectrochimica Acta Part A: Molecular Spectroscopy, 31, 951-957.

[11] Omura, S., Nakagawa, A., Fukamachi, N., Otoguro, K. and Kobayashi, B. (1986) Aggreceride, a New Platelet Aggregation Inhibitor from Streptomyces. Journal of Antibiotics, 34, 1180-1181. https://doi.org/10.7164/antibiotics.39.1180

[12] Kim, Y.A., Park, M.S., Kim, Y.H. and Han, S. (2003) Synthesis of 1-lyso-2-Palmitoylrac-glycero-3-phosphocholine and Its Regioisomers and Structural Elucidation by NMR Spectroscopy and FAB Tandem Mass Spectrometry. Tetrahedron, 59, 29212928.

[13] Mechoulam, R., Ben-Shabat, S., Hanus, L., Ligumsky, M., Kaminski, N.E., Schatz, A.R., Gopher, A., Almog, S., Martin, B.R., Compton, D.R., Pertwee, R.G., Griffin, G., Bayewitch, M., Barg, J. and Vogel, Z. (1995) Identification of an Endogenous 2-Monoglyceride, Present in Canine Gut, That Binds to Cannabinoid Receptors. Biochemical Pharmacology, 50, 83-90.

[14] Aizpurua-Olaizola, O., Elezgarai, I., Rico-Barrio, I., Zarandona, I., Etxebarria, N. and Usobiaga, A. (2016) Targeting the Endocannabinoid System: Future Therapeutic Strategies. Drug Discovery Today, 22, 105-110.

[15] Konishi, T., Satsu, H., Hatsugai, Y., Aizawa, K., Inakuma, T., Nagata, S., Sakuda, S., Nagasawa, H. and Shimizu, M. (2004) A Bitter Melon Extract Inhibits the P-Glycoprotein Activity in Intestinal Caco-2 Cells: Monoglyceride as an Active Compound. BioFactors, 22, 71-74. https://doi.org/10.1002/biof.5520220113

[16] Almoselhy, R.I.M., Allam, M.H., El-Kalyoubi, M.H. and El-Sharkawy, A.A. (2014) ${ }^{1} \mathrm{H}$ NMR Spectral Analysis as a New Aspect to Evaluate the Stability of Some Edible Oils. Annals of Agricultural Science, 59, 201-206.

[17] Gunstone, F.D. (1991) ${ }^{13}$ C-NMR Studies of Mono-, Di- and Triacylglycerols Leading to Qualitative and Semiquantitative Information about Mixtures of These Glycerol Esters. Chemistry and Physics of Lipids, 58, 219-224.

\section{Scientific Research Publishing}

Submit or recommend next manuscript to SCIRP and we will provide best service for you:

Accepting pre-submission inquiries through Email, Facebook, LinkedIn, Twitter, etc. A wide selection of journals (inclusive of 9 subjects, more than 200 journals)

Providing 24-hour high-quality service

User-friendly online submission system

Fair and swift peer-review system

Efficient typesetting and proofreading procedure

Display of the result of downloads and visits, as well as the number of cited articles

Maximum dissemination of your research work

Submit your manuscript at: http://papersubmission.scirp.org/

Or contact sar@scirp.org 